NBER WORKING PAPER SERIES

\title{
INTERNATIONAL PORTFOLIO CHOICE AND ASSET PRICING: AN INTEGRATIVE SURVEY
}

René M. Stulz

Working Paper No. 4645

\section{NATIONAL BUREAU OF ECONOMIC RESEARCH 1050 Massachusetts Avenue Cambridge, MA 02138 \\ February 1994}

I am grateful to Warren Bailey, Lee Riddick, Piet Sercu and Bruno Solnik for useful comments. This paper is part of NBER's research program in Asset Pricing. Any opinions expressed are those of the author and not those of the National Bureau of Economic Research. 


\title{
INTERNATIONAL PORTFOLIO \\ CHOICE AND ASSET PRICING: \\ AN INTEGRATTVE SURVEY
}

\begin{abstract}
In general, theories of portfolio choice and asset pricing let investors differ at most with respect to their preferences, their wealth and, possibly, their information sets. If there are multiple countries, however, the investment and consumption opportunity sets of investors depend on their country of residence. International portfolio choice and asset pricing theories attempt to understand how the existence of country-specific investment and consumption opportunity sets affect the portfolios held by investors and the expected returns of assets. In this paper, we review these theories within a common framework, discuss how they fare in empirical tests, and assess their relevance for the field of intemational finance.
\end{abstract}

René M. Stulz

College of Business

The Ohio State University

1775 College Road

Columbus, OH 43210

and NBER 


\section{Introduction.}

In general, theories of portfolio choice and asset pricing let investors differ at most with respect to their preferences, their wealth and, possibly, their information sets. If there are multiple countries, however, the investment and consumption opportunity sets of investors depend on their country of residence. International portfolio choice and asset pricing theories attempt to understand how the existence of country-specific investment and consumption opportunity sets affect the portfolios held by investors and the expected returns of assets. In this paper, we review these theories within a common framework, discuss how they fare in empirical tests, and assess their relevance for the field of international finance.

At a point in time, an investor's consumption opportunity set is composed of the goods that the investor can consume and their relative prices. Consumption opportunity sets differ across countries when the relative prices of goods depend on where goods are located. An investor's investment opportunity set is described by the distributions of wealith available to that investor for each future date. If two investors who differ in their country of residence can obtain the same distributions of wealth for all future dates in terms of the same arbitrary numeraire, they have the same investment opportunity sets. Investment opportunity sets differ across countries when investment barriers introduce a wedge between returns on assets for residents and for non-residents.

In this paper, we first show that if investment and consumption opportunity sets do not differ across countries, the fact that countries use different currencies has no significant implications for portfolio choice and asset pricing. In this special case, the 
traditional approaches to portfolio choice and asset pricing apply. Whereas these models perform poorly in predicting asset holdings across countries, they have some success in explaining the cross-sectional variation in conditional expected returns across countries We then show how the predictions of the traditional models are affected if one allows for differences in consumption opportunity sets and discuss the empirical relevance of such an extension of traditional models. Finally, we allow for differences in investment opportunity sets. We conclude by focusing on the weaknesses of this literature and suggest directions for future research.

Whereas this paper reviews the existing literature on portfolio choice and international asset pricing, it makes no attempt to discuss every paper in this literature. As the reader will certainly notice, we neglect to talk about some important papers so that we can focus better on our main themes.

\section{The case of no differences in consumption and investment opportu- nity sets.}

We consider a world where asset prices and exchange rates are jointly lognormally distributed. There is only one consumption good. Trading in the consumption good and in financial claims is continuous and costless. Markets are perfect. There are no transaction costs, no transportation costs, no tariffs, no taxes, no restrictions on shortsales, no barriers to international investment. Each investor is a price-taker, has the same information, and is risk-averse.

Formally, we assume that the price of the $i-t h$ financial claim in country $j, l_{i}$, 
changes according to:

$$
\frac{d l_{y}}{l_{1}}=\mu_{1 y} d t+\sigma_{1 y} d z_{y}
$$

where $d z_{i j}$ is the instantaneous increment to a standard Wiener process, $\mu_{n}$ is the instantaneous expected return per unit of time, and $\sigma_{i j}$ is the instantaneous standard deviation of the return per unit of time.

When forming a portfolio, an investor from country $j$ is concerned about the real return of financial assets rather than their nominal return in currency $j$. With a single consumption good trading on perfect markets, it must be the case that the price of the good is the same in currency j, for all j's, irrespective of the country in which it is bought. In the literature on foreign exchange rate determination, this result is usually called the law of one price. More formally, if $p_{j}$ is the price of the consumption good in country $j$ and $e_{i j}$ is the price of currency $j$ in country $i$, the price of the consumption good in country $i$ is $p_{1}=e_{i j} p_{j}$

With our assumptions, there are no differences in investment opportunity sets across countries, meaning that an investor in country $h$, for all $h$ 's, would have the same wealth at each future date if he had the investment opportunities of an investor in country j, for all j's.

If investors have identical consumption and investment opportunity sets, there is no loss of generality in assuming that all investors compute the returns of assets using the same numeraire to form their portfolios. We could use any numeraire, but if we use a currency as the numeraire, each investor's indirect utility depends on his consumption 
expenditures in that currency as well as on the price of the consumption good in that currency. In contrast, if we use the consumption good as the numeraire and assume, as we do here, that the joint distribution of returns is constant, the utility of an investor depends only on the number of units of the consumption good he consumes and his portfolio decisions depend only on the mean and variance of the real rate of return on his portfolio. For simplicity, we therefore assume that all investors use the consumption good as the numeraire. To obtain real relurns, we need to specify the dynamics of the price of the consumption good. We assume that the price of the consumption good in currency j. $p_{j}$, follows:

$$
\frac{d p_{1}}{p_{1}}=\mu_{p_{1}} d t+\sigma \sigma_{p_{1}} d z_{p_{1}}
$$

for all $j$ 's. Using the dynamics for $p_{j}$ and for the relurn of the $i-$ th assel from country $j$, we can obtain the return of that asset in terms of the price of the consumption good:

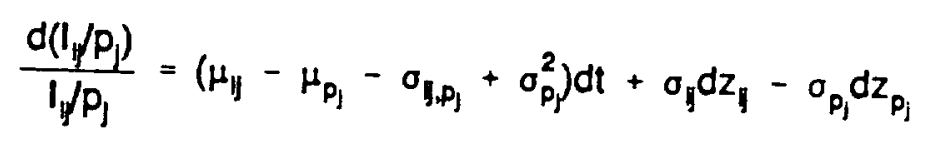

where $\sigma_{i j . p j}$ is the instantaneous covariance between the relurn of the $i-$ th asset of country $j$ and the rate of change of the price of the consumption good in terms of currency $j$.

We now assume that investors can freely lend and borrow at the instantaneous rate $r$ per unit of time in units of the consumption good. With this additional assumption, we now have a model in which we can completely ignore the existence of multiple countries and simply focus on the asset demands of investors in terms of the numeraire. With our assumptions, the joint distribution of real returns (i.e., returns in terms of the 
consumption good) is constant. This means that all the results of mean-variance portfolio choice theory apply in this case.' In particular, all risk-averse investors, irrespective of their preferences, hold their wealth in the risk-free asset and in one portfolio of risky assets that is common to all investors. Since the portfolio of risky assets is common to all investors, it must be the market portfolio of risky assets. A world where all investors hold the same portfolio of risky assets is the world of the Sharpe-Lintner capital asset pricing model.

In this world, the expected real excess return of an asset, namely the expected real return of the asset in excess of the real risk-free rate, obeys the following formula:

$$
\mu_{1 !}-\mu_{p_{1}}-\sigma_{1, p_{1}}+\sigma_{p_{1}}^{2}-r=\beta_{1}\left[\mu_{w}-r\right]
$$

where $\beta_{i j}$ is the instantaneous covariance between the real return of asset ij and the real retum of the world market portfolio divided by the instantaneous variance of the real retum of the world market portfolio, and $\mu_{w}$ is the instantaneous expected real return per unit of time of the world market portfolio. The world market portfolio is a portfolio that comprises all securities in the world in proportion to their capitalization relative to world wealth using a consumption good as the numeraire to measure world wealth and each security's capitalization. We call the model that yields equation (4) the international capital asset pricing model (ICAPM).

The ICAPM can be used to compute the expected real excess return of a nominal

1 See Huang and Litzenberger (1988) for a review of these results. 
default-free bond in country $i$ over a nominal default-free bond in country $j$ and hence makes it possible to value currency-dependent claims. Define $R_{i}$ to be the instantaneous nominal return on a bond whose return is certain in currency $i$. With this notation, the real return on a bond of country $i$ minus the real return on a bond of country $j$ is:

$$
\left(R_{1} d t-\frac{d p_{1}}{p_{1}}+\sigma_{p_{1}}^{2} d t\right)-\left(R_{j} d t-\frac{d p_{1}}{p_{1}}+\sigma_{p_{1}}^{2} d t\right)=R_{1} d t+\frac{d \theta_{1}}{\theta_{1}}-\sigma_{\theta_{1}}^{2} d t-\sigma_{\theta_{1}, p_{1}} d t-R_{1} d t
$$

where $e_{i j}$ is the price in currency $j$ of currency $i$ and where we use the fact that the law of one price implies $p_{j}=e_{i j} p_{i}$. Applying equation (4), we can obtain the expected real return on a long position in the bond of country $i$ financed by a short position in the bond of country $\mathrm{j}$ :

$$
R_{1}+\mu_{q}-\sigma_{a_{1}}^{2}-\sigma_{\theta_{1}, p_{1}}-R_{\jmath}=\beta_{0_{1}}\left[\mu_{w}-r\right]
$$

where $\beta_{\text {oif }}$ is the ratio of the instantaneous covariance of the rate of change of the exchange rate with the real return on the world market portfolio and of the instantaneous variance of the real return on the world market portfolio. The pricing relation implies that a portfolio with a long position in a nominal bond of country $i$ and a short position in a nominal bond of country $\mathrm{j}$ has a positive expected real return if the rate of change of the price of currency $i$ in country $j$ has a positive covariance with the real return of the world market portfolio. This is because, in this model, adding an asset whose real return has a positive covariance with the return of the world market portfolio to the portfolio of risky assets held by investors forces them to bear more risk. If this asset does not yield a risk premium, investors hold it short to decrease the risk of their portfolios and there is an 
excess supply of that asset.

The pricing relation can be looked at in a different way that is also useful. A wellestablished relation in international finance is the interest rate parity theorem, which here states that the instantaneous forward premium per unit of time on currency $i$ in terms of currency $j, f_{i j}$, is equal to $R_{i}-R_{i l}$, so that equation (6) becomes:

$$
\mu_{o_{1}}-t_{11}-\sigma_{o_{1}}^{2}-\sigma_{\theta_{1}, p_{1}}=\beta_{\theta_{1}}\left[\mu_{w}-r\right]
$$

Hence, the pricing equation can also be used to obtain the relation between the forward premium and the expected rate of growth of the exchange rate. It immediately follows from the pricing equation that the expected spot exchange rate exceeds the forward exchange rate if the covariance of the growth rate of the exchange rate with the world market portfolio is sufficiently large. This is because, in this case, the holder of a long forward contract bears risk and has to be rewarded for doing so by a positive expected payoff from the position. In the model of this section, a long position in a foreign currency yields a risk premium only to the extent that the risk of that position is not diversifiable. An important implication of equation (7) is that the expected excess real return on a forward contract differs from zero if the exchange rate has a $\beta$ equal to zero. In this case, the instantaneous forward premium must satisfy:

$$
\mu_{q_{1}}-f_{1}=\sigma_{Q_{1}}^{2}+\sigma_{\theta_{1}, P_{1}}
$$

Equation (8) implies that the diversifiability of exchange rate risk is not a sufficient condition for the forward premium to equal the expected rate of change of the spot exchange rate. In addition, it must be the case that the instantaneous variance of the rate 
of change of the exchange rate is equal to minus the instantaneous covariance of the rate of change of the exchange rate with the rate of change of the price of the consumption good in currency i. Equation (5) makes this result easily understandable. Investors care about the real return of the forward position. This real return is the payoff of the forward position divided by the price of the consumption good. The expected real payoff is therefore $E[(e-F) / P]$, where $e$ is the end-of-period exchange rate, $F$ is the (nonstochastic) forward rate, and $P$ is the end-of-period price of the consumption good. This expression is not equal to zero if $E(e)$ - $F$ equals zero because the end-of-period price of the consumption good is a random variable, so that $E[(e-F) / P]$ is not equal to $E(e-F) / E(P)$. Note that this result holds also if $\beta$ risk is not priced because investors are risk-neutral. In this section, all investors look at asset returns in the same way, so that the expected real return on forward contracts is the same for all investors in the world.

So far, we have formulated the pricing equation of the ICAPM using the consumption good as the numeraire. If $(A)$ the asset in country $j$ with an instantaneous risk-free nominal return in currency $\mathrm{j}$ has a beta equal to zero in terms of the pricing equation (4) and (B) the rate of growth of the price of the consumption good in currency $j$ is uncorrelated with nominal asset returns in that currency, then the ICAPM can be formulated using nominal returns in currency $j$. To see this, note that with our assumptions, the excess return of the $i$-th asset in country $j$ in terms of the price of the consumption good is: 


$$
\begin{aligned}
& \frac{d\left(I_{y} / p_{1}\right)}{l_{1} / p_{j}}-r d t=\left(\mu_{y}-\mu_{p_{1}}-\sigma_{I_{1} p_{1}}+\sigma_{p_{1}}^{2}-r\right) d t+\sigma_{y} d z_{y}-\sigma_{p_{1}} d z_{p_{1}} \\
& =\left(\mu_{1}-R_{1}+R_{f}-\mu_{p_{1}}+\sigma_{p_{1}}^{2}-r\right) d t+\sigma_{1} d z_{1}-\sigma_{p_{1}} d z_{p_{1}} \\
& =\left(\mu_{1} d t+\sigma_{1} d z_{1 j}-R_{j} d t\right)+\left(A_{j} d t-\mu_{p_{1}} d t-\sigma_{p_{1}} d z_{p_{1}}+\sigma_{p_{1}}^{2} d t-r d t\right) \\
& =\left(\frac{d l_{1}}{l_{1}}-R_{j} d t\right)+\left(R_{1} d t-\frac{d p_{1}}{p_{l}}+\sigma_{p_{1}}^{2} d t-r d t\right)
\end{aligned}
$$

where we take into account assumption $(B)$ that the rate of growth of $p_{j}$ is uncorrelated with nominal asset returns in currency j, i.e., $\sigma_{i, p i}=0$, when going from the first line to the second line of equation (9). This assumption makes it possible to decompose the excess real return of security ij into a nominal excess return which does not depend on the dynamics of the consumption good price and a real excess return which does not depend on the dynamics of the asset price. Without this assumption, the last line of equation ( 9 ) would depend on the instantaneous covariance between the nominal return of asset ij and the rate of change of the price of the consumption good in currency $j$. This covariance plays no role in nominal CAPMs. With assumption (A), the $\beta$ of the excess return of the nominal bond is zero. Consequently, the $\beta$ of asset ij computed using excess real retums equals the $\beta$ of the same asset computed using nominal excess returns in currency $j$. Further, the expected real excess return of asset ij equals its nominal expected excess return. Since this result holds for any asset ij, it also holds for the world market portfolio. Hence, we have shown that with our assumptions:

$$
\mu_{I}-R_{1}=\beta_{j}\left[\mu_{w}-R_{j}\right]
$$

where the $\beta$ can be computed using nominal or real excess returns and where $\mu_{\mathrm{m}}$ is the 
nominal expected return of the world market portfolio in currency $j$.

In general, nominal excess returns cannot be substituted for real excess returns, but there may be countries for which approximating real excess returns by nominal excess returns turns out to be harmless. Hence, if the ICAPM in real excess returns holds, it may be that an empiricist could reject it using nominal excess returns in one currency and could not reject it using nominal excess returns in another currency. One would be more comfortable using the nominal excess return approximation in countries where inflation has little systematic risk. It should be noted that tests of the CAPM that use only assets of one country are generally formulated using nominal excess returns; if such a practice makes sense for a particular country, then it makes equal sense to test the ICAPM in nominal excess returns from the perspective of that country.

How well does the ICAPM perform in an international setting? A number of papers provide unconditional tests of the ICAPM. Stehle (1977) uses monthly returns on U.S. securities and eight foreign indices to investigate whether U.S. assets are priced internationally, in the sense that risks that are diversifiable internationally but not domestically are not priced. He finds evidence in favor of this hypothesis, but the return for the zero-beta portfolio is too high to be consistent with the model. Korajczyk and Viallet (1989) provide evidence using a large number of securities from the U.S. and three foreign countries that the ICAPM outperforms the domestic CAPM in the sense that the average mispricing is smaller; however, in their various lests, they also find that the model leads to large pricing errors for small stocks, that the average mispricings are significantly different from zero for at least one market in all their specifications and that 
the performance of the ICAPM is better for more recent sample periods. Cumby and Glen (1990) and Harvey (1991) cannot reject the hypothesis that the world portfolio of the Morgan Stanley/Capital International indices is efficient in a setting where the portfolios on the efficient frontier are formed from national indices.

A number of recent studies investigate the model assuming that it holds period per period, allowing the joint distribution of asset returns to change over time and, for some studies, also allowing the price of risk to change over time. Merton (1973) shows that the CAPM holds period per period with changing investment opportunities either if investors have logarithmic utility functions or if they cannot use financial assets to hedge against changes in investment opportunities. It seems implausible that there are no assets whose return is correlated with changes in the distribution of asset returns. This means that the theoretical underpinnings of these studies are strongest for the case where investors all have logarithmic utility functions. Unfortunately, in that case, the price of risk is constant. Mark (1988), Giovannini and Jorion (1989) and McCurdy and Morgan (1991) use the model to investigate the risk premium incorporated in forward contracts. Whereas the model has some success in explaining conditional risk premia, it does not explain why conditional risk premia are so large for forward contracts. ${ }^{2}$ Harvey (1991) uses the model to examine the expected excess returns of the Morgan Stanley/Capital International monthly indices allowing for both changes in the betas of individual indices and changes in the price of risk. He finds that the model is useful to understand differences in conditional expected excess returns across countries; the model does not predict well the

\footnotetext{
2 See Backus, Gregory and Telmer (1993) for a discussion of this problem.
} 
conditional expected excess returns of some countries, however, suggesting that these countries are not well-integrated in world capital markets or that the model does not capture some priced risks in addition to the ICAPM systematic risk. Finally, Chan, Karolyi and Stulz (1991) test some implications of the model using daily data for the 1980s. They cannot reject the ICAPM in a model with a domestic and a foreign portfolio at a conventional significance level. However, they find that a two-beta model where each portfolio is a source of risk performs better than the single-beta model.

Several papers investigate the APT in an international context assuming identical consumption and investment opportunity sets across countries. The APT in this context relies on different assumptions about asset price and exchange rate dynamics than those we made in this section - namely, with the APT, the dynamics of asset and currency prices depend on multiple sources of risk. Solnik (1983) shows that if the exchange rates follow the same factor structure as stock prices, the APT holds internationally. In this case, the currency of denomination of returns becomes irrelevant and the priced factors can be obtained from the universe of stock returns. Hence, with Solnik's assumptions, the relation between the international APT and the domestic APT is the same as the relation between the ICAPM and the domestic CAPM. ${ }^{3}$ Cho, Eun and Senbet (1986) are the first to provide tests of the international APT and reject the joint hypothesis that markets are integrated and the APT is valid; however, their evidence is consistent with integration for subsets of countries. Gultekin, Gultekin and Penati (1989) and Korajczyk and Viallet (1990) show that the performance of the international APT depends on the regime for

\footnotetext{
${ }^{3}$ Ikeda (1991) shows how the model changes if Solnik's key assumption is relaxed.
} 
barriers to international investment. Korajczyk and Viallet find that the APT performs better than the CAPM with a value-weighted market portfolio but not than the CAPM with an equally-weighted portfolio. Somewhat surprisingly, they find that the domestic AP outperforms the international APT. Korajczyk and Viallet (1990) explore the joint returns of stocks and forward contracts in an APT setting with time-varying betas. They find that changes in the risk premia of factors derived from the equity markets do not span changes in risk premia on forward contracts. A possible explanation of this finding is that there are some priced risks in forward contracts that are not present in equities.

Whereas the ICAPM's performance for predicting conditional expected excess returns is good enough to lend some credibility to the model, the model fails dramatically in another dimension. The model predicts that investors hold the world market portfolio of risky assets irrespective of their country of residence. Yet, empirically, investors have a strong preference for the assets of their home country. "This preference of investors is the major empirical motivation for much of the literature on international portfolio choice and asset pricing. Theoretically, this literature proceeds from changing two assumptions that are crucial to the derivation of the ICAPM. The first assumption is that investors all have the same consumption investment opportunity set. Empirically, deviations from the law of one price resulting from the existence of costs to goods arbitrage are welldocumented and are consistent with the considerable variation in real exchange rates

4 See French and Poterba (1991), Cooper and Kaplanis (1990) and Tesar and Werner (1993) for evidence. 
documented in the literature. ${ }^{5}$ The second assumption is that the investment opportunity set is the same for all investors.

\section{The implications of differences in consumption opportunity sets.}

Consider now a world with many different goods whose relative prices change over time and may differ across countries and where investors' preferences over goods can differ according to their country of residence. Differences in preferences across countries imply that purchasing power parity does not hold since changes in relative prices have differential effects on the price of the consumption basket consumed by investors in different countries. Purchasing power parity also fails if investors have the same preferences but relative prices of goods differ across countries. Deviations from the law of one price could arise, for instance, because goods arbitrage involves transportation costs as modeled by Dumas (1992). If purchasing power parity does not hold, investors hold different portfolios across countries if they choose to hedge against unanticipated changes in the cost of their consumption basket since that cost evolves differentially across countries. Changes in the relative costs of consumption baskets affect asset demands and hence expected returns. This means that, in general, one would expect the investment opportunity set to change randomly over time if relative costs of consumption baskets change randomly over time.

\footnotetext{
${ }^{5}$ See, for instance, Cumby and Obstfeld (1984) for evidence and references to the literature.
} 
To understand the asset demands implied by this extended model better, ${ }^{6}$ define InP to be the $P \times 1$ vector of logarithms of goods prices in currency $i$. If the law of one price holds for a good, the location of the good is not a relevant attribute of the good in contrast, however, if the law of one price does not hold for a good, then its location is a priced attribute of the good. Hence, in the vector of goods prices, the goods for which the law of one price does not hold have to be treated as different goods if their location differs whereas location is irrelevant for the goods for which the law of one price holds.

With the formulation of the vector of goods prices used here, all investors can use the same currency to compute their optimal consumption and portfolio policies. This formulation of the investor's optimization problem is sufficiently general that it encompasses the case where the consumption opportunity sets of investors have no goods in common and the case where the consumption opportunity sets of investors are the same. We assume that the state of investment opportunities is characterized by a vector of $S$ states variables, $\underline{S}$. The first $P$ state variables are the logarithms of the consumption good prices.

Using currency $i$ as the numeraire, define $J(W, \underline{S}, t)$ as the indirect utility of wealth for an investor, where $W$ is his wealth in the currency of country i:

$$
J(W, S, t)=E_{d}\left[\operatorname{Max} \int_{\theta-0}^{\theta--} U(C(\theta), \ln P(\theta), \theta) d \theta\right]
$$

where $U(C(\theta), \ln P(\theta), \theta)$ is the indirect utility of consumption (i.e., the utility obtained by the investor by maximizing his utility function defined over goods, given expenditures $C(\theta)$

\footnotetext{
- The analysis of this section makes extensive use of Stulz (1981a).
} 
and prices of goods $\underline{P(\theta)}$ ). It follows from Stulz (1981a) that for this investor, the $n \times 1$ vector of risky asset holdings $\underline{w}$, where $n$ is the number of risky assets in currency $i$, is:

$$
W=\left(\frac{-J_{W}}{J_{w W} W}\right) V^{-1} \mu_{x}-\left(\frac{J_{W S}^{\prime}}{J_{w W} W} V^{-1} V_{S}\right.
$$

where $J_{w}$ is the partial derivative of the indirect utility of wealth with respect to wealth, $J_{w s}$ denotes the $S \times 1$ vector of partial derivatives of $J_{w}$ with respect to $S$, a prime denotes a transpose, $\mu_{x}$ is the $n \times 1$ vector of expected excess returns, $V$ is the $n \times n$ variancecovariance matrix of the returns of risky assets in currency $i$ in excess of the risk-free rate in currency $i, V_{s}$ is the $n \times S$ covariance matrix of excess returns with the rates of change of the state variables. Note that if we change the currency of denomination of returns, the asset with a non-stochastic return in currency $i$ has a stochastic return in the new currency of denomination of returns.

By inspection of equation (11), it follows that the investor's wealth can be decomposed into holdings of $S+1$ mutual funds, where $S$ is the number of goods. The first fund, with holdings proportional to $V^{-1} \mu_{x}$, is the portfolio of risky assets held by an investor who has logarithmic utility, since, for such an investor, the vector of partial derivatives of $J_{w}$ with respect to the state variables has only zeroes and the coefficient of relative risk aversion of the indirect utility function of wealth, $J_{W} / J_{w w}$, is equal to one. The next $S$ funds are optimal hedges against unanticipated changes in goods prices. With our formulation, the partial derivative of $J_{w}$ with respect to the price of goods the investor does not consume is zero, so that $S$ is the highest number of hedge portfolios an investor could take positions in. The matrix product $V^{-1} V_{S}$ yields $S$ vectors that correspond to the 
investments in risky assets of portfolios that are minimum-variance hedges for state variable changes; whereas the elements of these vectors do not sum to one, borrowing or lending at the risk-free rate can be used to form portfolios.

The asset demands given by equation (11) are general enough that the asset demands of existing international asset pricing models with constant and identical investment opportunities across countries are special cases. The asset demands of the existing models can be obtained from equation (11) as follows:

A. Solnik (1974a). Solnik's model is one that focuses on consumption basket differences across countries; in his model, the price of the consumption basket consumed by investors of country $j$ is constant in the currency of that country, so that exchange rates are relative prices of consumption baskets. To obtain Solnik's model, assume that (1) for each country there is a good whose price is constant in the currency of that country, (2) there are as many goods as there are countries, (3) investors consume only the good that has zero inflation in their country, and (4) the investment opportunity set is constant. In addition, Solnik makes the assumption that stock returns in their own currency are uncorrelated with exchange rates; this assumption was subsequently relaxed in an insightful paper by Sercu (1980). In this model, the return on default-free bonds of a foreign country is perfectly correlated with the growth rate of the exchange rate of that country. Hence, an investor of country $i$ can hold an asset that has a risk-free return in terms of his consumption basket, namely the bond of his country. This means that if asset demands in the model are computed in the same currency for all investors, each investor 
has a perfect hedge in terms of equation (11). If investors of country $i$ want to be long in the bond of their country, however, investors of foreign countries must be short that bond when the bond is in zero net supply; hence, the portiolio that is common to all investors must include short positions in the bonds held long for hedging purposes by some investors. In the following, we call the Solnik-Sercu model the SS-IAPM.

B. Grauer, Litzenberger and Stehle (1976). These authors, together with Kouri (1976) and Fama and Farber (1979), consider models where purchasing power parity holds and the investment opportunity set is constant. The model of Grauer, Litzenberger and Stehle is similar to the one of section 2 . They assume that there are multiple goods. However, in their model, investors consume the same goods and hence face the same consumption opportunity set. With constant expenditure shares, there is no loss of generality in assuming that investors consume a single good which is the same for all investors. One can therefore use that good as numeraire to obtain the ICAPM of section 2. The Fama and Farber (1979) model assumes that investors derive benefits from holding their domestic currency. This leads to different demands for bonds across investors from different countries because a short position in a country's risk-free nominal bond can be used to hedge a long position in cash balances from this country. Stockman (1980) goes further and assumes that investors hold currencies from all countries from which they import consumption goods.

C. Stulz (1981a) and Adler and Dumas (1983). These models allow for both stochastic inflation in each country and deviations from purchasing power parity. Whereas Adler and Dumas (1983) assume a constant investment opportunity set, Stulz (1981a) 
does not. In these models, a domestic bond is risky in real terms for domestic investors This means that investors who want to hold a risk-free real asset cannot do so. but instead can only hold a portfolio that has the lowest volatility in real terms. Since investors consume different consumption baskets across countries, the portfolio with lowest volatility of real returns differs across investors. Whereas Adler and Dumas (1983) posit dynamics for price levels in each country, Stulz (1981a) posits dynamics for goods prices so that the model encompasses the case where the law of one price holds for all goods but price indices differ across countries because of differences in tastes and the case where there are goods for which the law of one price does not hold, possibly because they are not traded internationally.

D. Kouri and DeMacedo (1978). They assume a constant investment opportunity set. In their model, each country has one good whose price is constant in the currency of that country, so that the exchange rate corresponds to a relative price. In this case, investors with constant expenditure shares can form a riskless portfolio by investing in each country's bond in proportion to the expenditure share of the good of that country. Krugman (1981) shows that the implications of this case for asset demands depend on the investors' degree of relative risk aversion, in the sense that investors with a relative risk aversion coefficient smaller than one will choose not to hedge against changes in relative prices; Stulz (1983) shows that this result holds generally only if investors have constant expenditure shares and derives results that do not rely on the assumption of constant expenditure shares. 
Whereas the composition of the hedge portfolios depends on the assumptions made about exchange rate dynamics, their relevance for how investors allocate their wealth is a function of the degree of risk-aversion of investors. If investors have logarithmic utility, they take no positions in assets to hedge against changes in prices. It can be shown that if investors all have logarithmic utility, they all hold the same portfolio, which has to be the world market portfolio irrespective of how they allocate their consumption expenditures across goods. If consumption baskets differ across investors with relative risk-tolerance coefficients different from one, one can still view them as holding the portfolio they would hold if they had logarithmic utility plus positions in $S$ hedge portfolios. However, in that case, there is no reason for the world market portfolio to be efficient for each investor since investors compute their returns differently. To see this, suppose that there is a security that has a riskless return in terms of the consumption basket of a particular investor. Obviously, this security will be an efficient portfolio for that investor. Hence, for this investor, the efficient frontier can be formed by taking combinations of that security and the portfolio the investor would hold if he had logarithmic utility. Consider now a second investor whose consumption basket is such that no risk-free security exists for that individual. For this second investor, the risk-free security of the first investor will not be an efficient portfolio and hence the efficient frontiers of the two investors differ. If there are only these two investors in the world, the world market portfolio is a weighted average of the portfolios they hold and hence is on neither efficient frontier.

The asset demands of equation (11) can be aggregated across all investors. In 
equilibrium, the aggregate demand for assets must equal their supply. This equilibrium condition implies that expected excess returns must satisfy the following equation:

$$
\left.V w^{s} H\right]^{\prime} M^{-1}\left[\begin{array}{ll}
\mu_{w} & \mu_{H}
\end{array}\right]=\mu_{x}
$$

where $w^{s}$ is the world market portfolio, $H$ is $V^{-1} V_{s}, M$ is $\left[w^{s} H\right]^{\prime} V\left[H w^{s}\right], \mu_{w}$ is the expected excess return on the world market portfolio, and $\mu_{H}$ is the vector of expected excess returns on the portfolios that hedge investors against state variable risks. In this model, if investors actively hedge against state variable risks, assets that help all investors to hedge have lower expected excess returns since such assets have a higher demand than in the ICAPM. By construction, the asset pricing model derived here subsumes the various other models presented in the literature which differ with respect to their assumptions concerning the dynamics of the consumption opportunity sets of investors that reside in different countries and the dynamics of the investment opportunity set.

As with the ICAPM, the forward rate is a biased predictor of the future spot exchange rate even if there is no risk premium. However, the approach in this section makes it clear that the expected real return on forward contracts is not the same for all investors if investors have different consumption opportunity sets or different preferences for goods. For instance, Solnik's model implies that if uncovered interest rate parity holds between countries $j$ and $i$ from the perspective of investors from country $j$, a forward contract to buy currency $\mathrm{j}$ has a positive expected excess return for investors from country i since $E(e-F)=0<E(1 / e-1 / F)$ from Jensen's inequality. Hence, in his model, investors in country $j$ want to be long currency $i$ if there is no risk premium; investors of country $i$ are willing to be short currency $i$ (long currency j), only if they get a positive 
expected excess return on the long currency j position. Black (1991) shows that this implies that in this class of models investors have long positions in foreign currencies, so that their equity holdings in foreign countries are not completely hedged against exchange rate risk.

In the SS-IAPM, the hedge portfolios are the foreign currency bonds. It turns out that, in that model, one can obtain an ICAPM that can be used to price all risky assets except the foreign currency bonds. In that version of the model, the excess returns are the excess returns of zero investment portfolios of stocks hedged against exchange rate risk rather than the excess returns in a common numeraire used in the model presented in section $2 .^{8}$ If the hedge portfolios are foreign currency bonds, the SS-IAPM discussed here may differ little empirically from the ICAPM discussed in the first section. To see this, note that unconditionally the two models differ because in the SS-IAPM the expected excess return on risky assets depends on their exposure to foreign currencies and hence is affected by the risk premium associated with bearing that exposure. However, unconditionally, the risk premium on positions in foreign currencies is generally not statistically different from zero. ${ }^{9}$ Hence, in unconditional tests, the SS-IAPM and the ICAPM are unlikely to be distinguishable if one focuses on the additional risk premia associated with the SS-IAPM. Conditionally, the expected return on forward positions is

${ }^{7}$ See Adler and Prasad (1992) for a critique and elaboration of Black's approach.

- Empirically, positions in foreign indices financed through foreign borrowings are generally hedged against foreign exchange risk. See, for instance, Adler and Simon (1986) and Bailey, $\mathrm{Ng}$ and Stulz (1990) for evidence.

See Hodrick (1987) for a review of the literature on the pricing of foreign exchange risk in forward contracts. 
not zero, so that the models can be distinguished empirically using conditional tests. Whereas the ICAPM can be interpreted as holding period by period under the assumption of logarithmic utility, the SS-IAPM collapses into the ICAPM when investors have logarithmic utility because, in that case, investors' portfolios do not depend on the numeraire. Hence, the theoretical underpinnings of conditional tests of the SS-IAPM are unclear.

An important difference between the model of section 2 and the model of this section is that the ICAPM predicts that all investors hold the same portfolio of risky assets, whereas the model of this section (which we call the IAPM) does not. With the ICAPM, there are no risk-free nominal assets outstanding if all nominal assets are in zero net supply, since all investors would want to have identical positions in these assets. In contrast, with the model of this section, investors have positions in nominal assets that depend on their country of residence. For instance, in the SS-IAPM, investors have demands for foreign bonds which are in zero net supply. ${ }^{10}$ In the presence of differential demands for bonds, the logarithmic portfolio includes positions in bonds. Hence, the portfolio held by a logarithmic investor differs in its composition depending on which model holds. There is evidence in Stambaugh (1982) that, in a domestic context, the inclusion of bonds in a portfolio has little impact on tests of whether that portfolio is mean-

${ }^{10} \mathrm{Frankel}$ (1979) derives related asset pricing results assuming that nominal bonds are outside assets, in which case they belong to the market portfolio. In this case, the risk premium on forward contracts depends on the supplies of nominal assets. In Frankel (1982) and other papers he provides evidence that the asset demands implied by the ex post risk premia on foreign exchange do not correspond to the existing supplies of nominal assets in the context of his model. 
variance efficient; such evidence makes it unlikely that unconditional empirical tesis could determine whether the logarithmic portfolio includes positions in foreign bonds that have negligible unconditional expected excess returns. However, whereas the tangency portfolio of the ICAPM is a prion observable in the sense that if one knows the asset supplies, one knows that portfolio, the same is not true for the tangency portfolio of the IAPM since knowing the asset supplies does not yield the tangency portfolio.

Whereas many models assume a constant investment opportunity set, equation (12) is consistent with an investment opportunity set which changes stochastically. Allowing the investment opportunity set to change stochastically seems important given the evidence that conditional risk premia on foreign exchange are significant and variable." Such an extension implies that investors not only hedge against unanticipated changes in relative prices, but also against unanticipated changes in the joint distribution of asset returns. Hence, equation (12) incorporates additional hedge portfolios. Empincally, we therefore end up with a model where the tangency portfolio is not observable and tests of that model are mispecified if hedge portfolios are omitted. This suggests that it is better to focus on an alternative representation of expected returns that exploits the condition that the expected product of the payoffs of assets and marginal utility has to be the same for all assets to insure that expected utility is maximized. Exploiting this condition in a continuous-time model leads to a pricing equation where the risk of assets is measured in terms of the covariance of their return with respect to

$"$ It is possible for the investment opportunity set to change over time and for all investors to have the same constant, identical consumption opportunity set. Hodrick (1981) presents such a model in an international setting. 
consumption growth. Assuming constant expenditure shares so that there is a welldefined price index, we can write that:

$$
\mu_{1}-r=\beta_{1}\left[\mu_{c}-r\right]
$$

where the left-hand side is the expected excess real return on asset $i, \beta_{\text {, }}$ is the beta of the real return of asset i with respect to the real return of the portfolio whose real return is the most highly correlated with consumption growth, and $\mu_{c}$ is the expected real rate of return on that portfolio. In equilibrium, this equation holds for any country and nence can be implemented using the price index of just one country. It could be the case, however, that the equation holds for one country and not another simply because the first has access to all securities without barriers to international investment whereas the other does not. Hence, a test of whether markets are internationally integrated is whether the equation holds in terms of world consumption. The consumption beta model has the advantage of holding irrespective of the assumptions made about exchange rate dynamics, so that financial economists do not need to commit themselves to a specific model of exchange rate dynamics to investigate the pricing of risky assets across countries. Since it allows for changes in the investment opportunity set, it is generally consistent with general equilibrium models. In contrast, the IAPMs with constant investment opportunity sets are unlikely to be supported by general equilibrium models because, since optimal portfolios differ across countries if investors do not have logarithmic utility, relative wealth is not constant across countries. Changes in relative wealth imply changes in asset demands and hence in risk premia which are inconsistent with a model with a constant investment opportunity set. If investors have logarithmic 
utility, investors' wealth will be perfectly correlated even if their consumption opportunity sets and their consumption preferences can differ across countries as shown in Stulz (1987) for a model with money and non-traded goods.

The IAPMS that imply that hedging portfolios are foreign bonds have not been tested extensively. Solnik (1974b) tests his model using stock returns from nine countries. He finds that there is substantial evidence for the presence of national factors in pricing of common stocks. However, his sample covers the period of March 1966 to April 1971 , which is a period where one would expect substantial barriers to international investment to be in place. Roll and Solnik (1977) test the model for the pricing of forward contracts and find supportive evidence. Recently, Chan, Karolyi and Stulz (1992) provide a test of the Solnik model allowing for time-varying variances and covariances for the excess returns of the S\&P 500 and of the Nikkei 225 (which is assumed to proxy for the market portfolio of non-U.S. assets). With their dataset, they can reject neither the ICAPM nor the Solnik model. Dumas and Solnik (1992) provide conditional tests of the SS-IAPM: their results indicate that exposure to exchange rates significantly affects expected returns, but mostly in explaining the expected returns of short-term bonds. ${ }^{12}$

Recent papers emphasize the importance of allowing expected returns to change over time. Ferson and Harvey (1992), Campbell and Hamao (1992) and Bekaert and Hodrick (1992) show that expected returns of individual countries are forecastable and that the cross-sectional variation of expected returns is related to the variables that

${ }^{12}$ See also Lewis (1988). She tests a model that is similar to the Adler and Dumas model for currencies, implicitly assuming that currency returns are uncorrelated with stock returns. Her results are generally negative. 
explain how expected returns vary over time. ${ }^{3}$ The se papers also suggest that the crosssectional variation in expected returns can be understood better using additional measures of risk besides systematic risk. For instance. Ferson and Harvey (1992) show that a multi-beta model performs better than the ICAPM of section 2 . Whereas these papers indicate that time-variation in expected returns is important, they cannot be viewed as formal tests of equation (12) since they show either that more than one latent variable is needed to characterize changes in expected returns or that expected returns are related to exposure to pre-specified factors. In contrast, however, the consumption-beta model has been tested and seems to do reasonably well at explaining the cross-sectional distribution of returns across countries (Wheatley (1988) and Cumby (1990)) and at explaining the returns on forward contracts (Cumby (1988)). In Wheatley's case, the model does poorly for a few countries that may not be well-integrated in international asset markets, whereas in Cumby's case the model does much better for the 1980s than for a longer sample period. Although the theoretical case for the consumption ICAPM is strong, testing of the model suffers from the deficiencies of the consumption data which limit the power of tests.

The usefulness of international asset pricing models can be investigated by considering their implications for asset demands as well as their implications for expected excess returns. The SS-IAPM model predicts that investors hold identical common stock portfolios and hence cannot explain the home-bias in portfolio holdings. The Adler and

${ }^{13}$ Solnik (1991) also provides evidence that expected returns are forecastable, but his work focuses on the implications of forecastability for portfolio choice rather than for asset pricing. 
Dumas model does not make the same prediction, but they argue that empirically it is likely to yield the same conclusion as the SS-IAPM because there is little variability in inflation rates and, for a particular investor, the hedge portfolio is most likely to be composed of the default-free bonds from his country. In contrast, there is no a prion reason why the consumption asset pricing model cannot explain asset holdings across countries since it allows relative stock holdings to differ across countries. In principle, any bias in equity holdings can be consistent with the consumption asset pricing model; however, the literature has failed either empirically or theoretically to provide convincing evidence that the bias results from differences in consumption preferences and opportunity sets. For instance, Uppal (1993) builds on the model of departures from the law of one price of Dumas (1992) and finds the paradoxical results that, in his model, if investors choose to hedge against deviations from the law of one price, the home-bias will be exhibited by investors with a relative risk-aversion coefficient below one. Hence, in his model, investors exhibit a home-bias only if their degree of risk-aversion is low. On the empirical front, Cooper and Kaplanis (1990) provide some evidence that the magnitude of the home-bias cannot be explained by a model with deviations from purchasing power parity such as the Adler and Dumas model.

\section{Barriers to international investment.}

Existing evidence on the ICAPM and on the international consumption asset pricing model shows that the models do not work well for some countries. Viewed more broadly, tests of these models against a null hypothesis that the relationships posited by these 
models do not hold are not very powerful against alternative hypotheses that there are some barriers to international investment. To understand this, note that if there are barriers to international investment that imply that returns in a country differ from those predicted by the ICAPM or consumption-based model, but the abnormal returns implied by the barriers are small, empirical tests will not be able to find evidence of these abnormal returns. Yet, for the central question of why investors prefer home-country assets, relatively small abnormal returns due to barriers to international investment can have a big impact on asset holdings and can explain the home-country bias. ${ }^{14}$ To seek evidence on barriers to international investment, the lack of power of asset pricing tests with unspecified null hypotheses has led to two approaches. First, models that explicitly specify the impact of barriers to international investment have been developed and tested. Second, authors have focused on cases where more direct approaches permit more precise measurement of barriers to international investment. We discuss these two literatures in turn.

To understand the impact of barriers to international investment on asset demands, consider again the asset demands developed in section 3, but now allow for the existence of barriers to international investment whereby a domestic investor holding asset ij long must pay a tax per unit invested of $\delta_{\mathrm{kj}}$. A domestic investor holding the same asset short must pay a tax per unit invested of $\delta_{\text {s.j. }}$ In this case, a straightforward extension of Stulz (1981b) shows that asset demands can be written:

\footnotetext{
14 See Cooper and Kaplanis (1990) who argue that a model with deadweight costs of $1 \%$ per annum can generate the observed home bias in portfolios.
} 


$$
\begin{aligned}
& \left.V^{-1}\left[\left(\frac{-J_{w}}{J_{w w} W}\right) \mu_{w}-\delta_{1}\right]-\frac{\mu}{J_{w w} W}\right]+V^{-1} V_{s}\left(\frac{-J_{w s}}{J_{w w} W}\right)-s<1 \\
& V^{-1}\left[\left(\frac{-J_{w}}{J_{w w} W}\right)\left[\mu_{w}-\delta_{d}\right]-\frac{\omega}{J_{w w} W}\right]+V^{-1} V_{s}\left(\frac{-J_{w s}}{J_{w w} W}\right)-1>s
\end{aligned}
$$

where $\delta_{1}$ and $\delta_{3}$ are the vectors of tax rates on long and short positions respectively, $\mu$ and $\omega$ are the vectors of Lagrangean multipliers associated with the constraints that long positions and short positions must be positive. $I$ and $s$ are respectively the long and short positions of investors expressed as fractions of their wealth. Since the tax rates differ for long and short positions, we now have two sets of asset demands. These asset demands are formulated using inequalities because it is possible for an investor to neither want a long nor a short position in an asset. In other words, in this model it is possible for some assets to be non-traded. Intuitively, with barriers to international investment, the expected excess return on an asset is lower than without barriers. For an investor to still be willing to take a position in the asset, it must be that the diversification or hedging benefits that come from this asset must be large enough to offset its lower return. Not surprisingly, the barriers to international investment considered here reduce holdings of foreign assets because, being non-stochastic, they do not affect the variance of the return of a portfolio held without barriers, but decrease its expected excess return.

The asset demands given in equation (14) are the canonical asset demands of models with investment barriers, since these models can be obtained from equation (14) by making the following assumptions: 
A. Black (1974). Black's model assumes that investors face different tax rates depending on their country of residence and that investment and consumption opportunity sets are constant. These taxes are imposed on the absolute amount invested in a country and hence are not taxes on income. The model has no short-sale restrictions. Since the tax rate is assumed to be the same on short and long positions, investors pay negative taxes on short positions since taxes paid are the tax rate times the size of the position Further, the investment opportunity set is constant and identical for all investors. Since there are no short-sale restrictions, his model can be obtained by setting $\delta_{\mathrm{iij}}=\delta_{\mathrm{si}}$ for all assets, in which case the distinction between short and long positions becomes irrelevant, and by assuming that relative prices are constant. With this model, the asset demands differ across countries because tax rates differ across countries.

B. Stulz (1981b). The interest of the Black model is largely that the tax rates can proxy for costs of international diversification. With this interpretation, the tax rates can proxy for per period pecuniary or non-pecuniary costs of holding foreign assets. The Black model implies, however, that short positions in foreign assets are subsidized since they have negative tax payments. The Stulz (1981b) model assumes that investors pay a positive per-period tax whether they are long or short in a foreign asset and otherwise makes the same assumptions as those required by the Black model. A direct implication of this positive tax assumption is that some domestic assets are held only by domestic investors because they do not provide diversification benefits large enough to overcome the tax.

C. Errunza and Losq (1985) and Eun and Janakiramanan (1986). These papers 
assume that some securities are not available internationally, which amounts to assuming that the tax rate is infinite for some securities in the Stulz model. The Errunza and Losa (1985) paper considers the case where securities from a country are not available to foreign investors, but investors from that country can invest abroad. In contrast, in the Eun and Janakiramanan (1986) paper, the country with restrictions makes some securities available, but possibly only to a limited extent.

There exist a number of empirical tests of these models with barriers. Wheatley (1988) uses the Stulz (1981b) model as the alternative to the international consumption pricing model discussed in the previous section and finds evidence of significant barriers to international investment for some countries. Errunza and Losq provide empirical evidence supportive of their model. Hietala (1989) tests a model similar to the Eun and Janakiramanan (1986) model using Finland as the country with restricted shares and finds supportive evidence.

The problem with using asset pricing models to test for the existence of barriers to international investment is that such tests typically lack power. The estimates are sufficiently imprecise that tests that use market integration as the null hypothesis cannot reject the existence of economically significant barriers. To wit, a barrier that reduces the return on foreign securities by 200 basis points a year would be economically significant. For instance, such a barrier would be sufficient to explain much of the home-bias in portfolio holdings (see Cooper and Kaplanis (1990)). However, asset pricing tests typically cannot reject the hypothesis that such a barrier exists when they fail to reject market 
integration. An alternative approach to studying barriers to international investment is to examine whether the law of one price holds for securities. This approach compares prices of identical securities that trade in different countries. The most common tests of the law of one price on security markets focus on the interest rate parity theorem. Recently, however, a number of papers have investigated the pricing of similar securities on different markets.

Much attention has been given to the Euromarkets in this research because of the often made claim by corporate treasurers that they can borrow more cheaply on these markets than on domestic markets. There is some limited evidence of profitable arbitrage transactions where corporations could borrow more cheaply on the Eurobond markets than the U.S. Treasury could in the U.S. markets at the same time. There is also substantial evidence that issuing securities offshore could increase shareholder wealth relative to issuing in domestic markets when foreign holders of bonds issued in the U.S. had to pay a withholding tax. ${ }^{15}$ Whereas this evidence focuses on corporate bonds, there is also some related evidence on equities. In particular, there is substantial evidence that stocks that differ only because of their availability to foreign investors sell for different prices and that the more widely available stocks sell for a relatively higher price (see, for instance, Hietala (1989) and Stulz and Wasserfallen (1992)).

\footnotetext{
${ }^{15}$ See Kim and Stulz (1989) for evidence and references to other papers studying the Euromarkets.
} 


\section{An assessment of the current state of international finance.}

At this point, the international finance literature has a number of theoretical models that are consistent with the most salient facts about international capital markets. The empirical work has progressed dramatically during the 1980 s with the greater availability of data. The main conclusion of this empirical work seems to be that when one focuses on indices across countries, much of the evidence is consistent with market integration. The problem with most existing empirical work, though, is that the tests seem to have limited power in assessing the importance of barriers to international investment. Further, if the home-bias is the outcome of investors' optimization, existing tests of international asset pricing models do not have enough power to provide support for this view. Finally, the models seem to fare poorly when tests investigate the relurns of individuals stocks and/or bonds. ${ }^{18}$

A more fundamental criticism can be directed at much of the existing literature reviewed in this paper, though. Neither the ICAPM nor the IAPM are specifically international models. Though these models allow for differences in inflation rates across countries, they could as well be used to characterize asset demands within the U.S. Why should the differences in consumption opportunities between Paris and Geneva be more important than differences in consumption opportunities between Anchorage and Key West? Though some argue that departures from PPP make asset pricing models truly international, would somebody be willing to argue that the law of one price holds better

${ }^{16}$ In a recent study, Bansal, Hsieh and Viswanathan (1993) write that "The challenge in international asset pricing is in explaining forward contracts and bond returns and not stock index returns." (p. 1742). 
between Anchorage and Key West than it does between Paris and Geneva? There is a fundamental difference between Paris and Geneva which does not exist between Anchorage and Key West. Paris and Geneva belong to different countries. Governments affect saving and investment decisions of investors in crucial ways:

1) They define the rights and obligations of the holders of financial assets issued within a country and can change these definitions. This power allows them to discriminate against or in favor of foreign investors.

2) They define the rights and obligations of the residents of a country. In particular, they determine how income is taxed, how assets are traded and how residents can invest abroad.

3) They define legal tender within the country. Hence, they make it necessary for investors to hold the currency of the country, in contrast to many models of international asset pricing where the location of an investor is irrelevant in his portfolio decisions.

The fact that the existence of countries has implications for the saving and investment decisions of investors is the foundation of international finance and makes international finance a field that is distinct from domestic finance. Hopefully, much of future research in international finance will focus on questions that would not arise if there was only one country.

A less ambitious but more clearly defined research agenda for the field of international finance should include the following avenues of research:

1. One approach to obtain more powerful tests of international asset pricing models 
is to use more securities. Most existing empirical work uses indices; work that uses large numbers of securities for different countries seems to be primarily devoted to studying the relation between asset returns in two countries rather than to testing international asset pricing models. ${ }^{17}$

2. Most empirical work tests the hypothesis of market integration against an unidentified alternative hypothesis. Since there exist well-specified models with barriers to international investment, tests could gain more power by searching for pricing patterns that are consistent with specific types of barriers to international investment.

3. Whereas taxation regimes differ across countries, we have little understanding of how these differences affect porfolio decisions, expected returns, asset supplies and the growth of markets.

4. It is now clear that holdings of foreign securities, and hence the extent of the home bias, change over time. A challenge for both theoretical and empirical work is to explain these changes and to construct models that are consistent with such changes. Presumably, one reason for such changes is that barriers to international investment change over time, but we have little in the way of theory that explains why such barriers exist or why they change over time.

5. Most models reviewed in this paper take exchange rate dynamics as given. Models which describe more explicitly the determinants of exchange rate changes should

${ }^{17}$ For instance, Jorion and Schwartz (1986) investigate jointly the U.S. and Canadian stock markets and find evidence against integration. More recently, Mittoo (1992) finds that interlisted stocks seem priced in an integrated market, whereas Canadian slocks trading only in Canada only do not. 
provide more testable restrictions on asset prices and make clearer which dynamics for asset prices are consistent with existing theories of exchange rate determination. ${ }^{18}$

18 See Uppal (1993) for work that attempts to use the Dumas (1992) model to address this issue. Models without frictions in commodity markets include Stockman (1980). Stulz $(1984,1987)$ and Svensson (1987). 


\section{References}

Adler, M. and Dumas, B., 1983, International portfolio choice and corporation finance: A synthesis, Journal of Finance 38, 925-984.

Adler, M. and B. Prasad, 1991, On universal currency hedges, unpublished manuscript.

Adler, M. and D. Simon, 1986, Exchange risk suprises in international portfolios, Journal of Portfolio Management 12, 44-53.

Backus, D.K.G., A.W. Gregory and C.I. Telmer, 1993, Accounting for forward rates in markets for foreign currency, Journal of Finance 48, 1887-1909.

Bansal, R., D.A. Hsieh, and S. Viswanathan, $A$ new approach to international arbitrage pricing, Journal of Finance 48, 1719-1749.

Bailey, W., E. Ng and R.M. Stulz, 1992, Optimal hedging of stock portfoios against foreign exchange risk: The case of the Nikkei 225, Global Finance Journal 3, 97-114.

Bekaert, G. and R.J. Hodrick, 1992, Characterizing predictable components in excess returns on equity and foreign exchange markets, Journal of Finance 47, 467-510.

Black, F., 1974, International capital market equilibrium with investment barriers, Journal of Financial Economics 1, 337-352.

Black, F., 1991, Equilibrium exchange rate hedging, Journal of Finance 45, 899-909.

Campbell, J.Y. and Y. Hamao, 1992, Predictable stock returns in the United States and Japan: A study of long-term capital market integration, Journal of Finance 47, 4369.

Chan, K.C., G.A. Karolyi and R.M. Stulz, 1992, Global financial markets and the risk premium on U.S. equity, Journal of Financial Economics 32, 137-167. 
Chen, N.-F., R.R. Roll and S.A. Ross, 1986, Economic forces and the stock market, Journal of Business 59, 383-403.

Cho, D.C., Eun, C.S. and L.W. Senbet, 1986, International arbitrage pricing theory: An empirical investigation, Journal of Finance 41, 313-329.

Cooper, I.A. and E. Kaplanis, 1990, What explains the home bias in portfolio investment, unpublished working paper, London Business School.

Cumby, R.E., 1988, Is it risk? Explaining deviations from uncovered interest rate parity, Journal of Monetary Economics 22, 279-299.

Cumby, R.E., 1990, Consumption risk and international equity returns: Some empirical evidence, Journal of International Money and Finance 9, 182-192.

Cumby, R.E. and J.D. Glen, 1990, Evaluating the performance of international mutual funds, Journal of Finance 45, 497-522.

Cumby, R.E. and M. Obstfeld, 1984, International interest rate and price level linkages under floating exchanges: A review of recent evidence, in J.F.O. Bilson and R. Marston, eds., Exchange rate theory and practice, University of Chicago Press, Chicago, IL.

Dumas, B., 1992, Dynamic equilibrium and the real exchange rate in a spatially separated world, Review of Financial Studies 5, 153-180.

Dumas, B. and B. Solnik, 1992. The world price of exchange rate risk, unpublished working paper, HEC, Paris.

Errunza, V. and E. Losq, 1985, International asset pricing under mild segmentation: Theory and tests, Journal of Finance 40, 105-124. 
Eun, C.S. and B.G. Resnick, 1988, Exchange rate uncertainty, forward contracts, and international portfolio selection, Journal of Finance 43, 197-216.

Eun, C.S. and S. Janakiramanan, 1986, A model of international asset pricing with a constraint on the foreign equity ownership, Journal of Finance 44, 1025-1038.

Fama, E.F. and A. Farber, 1979, Money, bonds and foreign exchange, American Economic Review 69, 639-649.

Ferson, W.E. and C.R. Harvey, 1991, The risk and predictability of international equity returns, Review of Financial Studies 6, 527-567.

Frankel, J., 1979, The diversifiability of exchange risk, Journal of International Economics 9. 379-394.

Frankel, J., 1982, In search of the exchange-risk premium: A six-currency lest assuming mean-variance optimization, Journal of International Money and Finance 1, 255274.

French, K.R. and J.M. Poterba, 1991, Investor diversification and international equity markets, American Economic Review, Papers and Proceedings, 222-226.

Giovannini, A. and P. Jorion, 1989, The time variation of risk and return in the foreign exchange and stock markets, Journal of Finance 44, 307-325.

Grauer, F.L.A., R.H. Litzenberger and R.S. Stehle, 1976, Sharing rules and equilibrium in an international capital market under uncertainty, Journal of Financial Economics 3, 233-256.

Gultekin N.M., N.B. Gultekin and A. Penati, 1989, Capital controls and international capital market segmentation: The evidence from the Japanese and American stock 
markets, Journal of Finance 44, 849-869.

Harvey, C.R., 1991, The world price of covariance risk, Journal of Finance 46, 111-157.

Hietala, P.K., 1989, Asset pricing in partially segmented markets, Journal of Finance 44 , $697-715$

Hodrick, R., 1981, International asset pricing with time-varying risk premia, Journal of International Economics 11, 573-575.

Hodrick, R.J., 1987, The empirical evidence on the efficiency of forward and futures markets, Hawwood Academic Publishers, London.

Huang, C.-F. and R.H. Litzenberger, 1988, Foundations for financial economics, NorthHolland, New York.

Ikeda, S., 1991, Arbitrage asset pricing under exchange risk, Journal of Finance 46, 447 . 455.

Jorion, P. and E. Schwartz, 1986, Integration versus segmentation in the Canadian stock market, Joumal of Finance 41, 603-613.

Kim, Y.C. and R.M. Stulz, 1989, The Eurobond market and corporate financial policy: A test of the clientele hypothesis, Joumal of Financial Economics 22, 189-225.

Korajczyk, R.A. and C.J. Viallet, 1989, An empirical investigation of international assel pricing, Review of Financial Studies 2, 553-585.

Korajczyk, R.A. and C.J. Viallet, 1990, Equity risk premia and the pricing of foreign exchange risk, Working Paper \# 75, Northwestern University.

Kouri, P., 1976, The determinants of the forward premium IIES Seminar Paper 62, University of Stockholm, Stockholm, Sweden. 
Kouri, P. and B. de Macedo, 1978, Exchange rates and the international adjustment process, Brookings Papers on Economic Activity, 111-150.

Krugman, P., 1981, Consumption preferences, asset demands, and the distribution effects in international financial markets, Working Paper No. 651. National Bureau of Economic Research, Boston, Massachusetts.

Lewis, K.K., 1988, Inflation risk and asset market disturbances: The mean-variance model revisited, Journal of International Money and Finance 7, 273-288.

Mark, N.C., 1988, Time-varying betas and risk premia in the pricing of forward foreign exchange contracts, Joumal of Financial Economics 22, 3-18.

McCurdy, T.H. and I.G. Morgan, 1991, Tests for a systematic risk component in deviations from uncovered interest rate parity, Review of Economic Studies 58 , $587-602$.

Mittoo, U.R., 1992, Additional evidence on integration in the Canadian stock market, Journal of Finance 47, 2035-2054.

Roll, R. and B. Solnik, 1977, A pure foreign exchange asset pricing model, Journal of International Economics 7, 161-179.

Sercu, P., 1980, A generalization of the international asset pricing model, Revue de l'Association Française de Finance 1, 91-135.

Solnik, B.H., 1974a, An equilibrium model of the international capital market, Journal of Economic Theory 8, 500-524.

Solnik, B.H., 1974b, The international pricing of risk: An empirical investigation of the world capital market structure, Journal of Finance 29, 48-54. 
Solnik, B.H., 1983, International arbitrage pricing theory, Journal of Finance 38, 449-457.

Solnik, B.H., 1991, Predictability of foreign asset returns, unpublished working paper, HEC, Fontainebleau, France.

Stambaugh, R.F., 1982, On the exclusion of assets from tests of the two-parameter model: A sensitivity analysis, Journal of Financial Economics 10, 235-237.

Stehle, R., 1977, An empirical test of the alternative hypotheses of national and international pricing of risky assets, Journal of Finance 32, 493-502.

Stockman, A.C., 1980, A theory of exchange rate determination, Journal of Political Economy 88, 673-698.

Stulz, R.M., 1981a, A model of international asset pricing, Journal of Financial Economics $9,383-406$.

Stulz, R.M., 1981b, On the effects of barriers to international investment, Joumal of Finance $36,923-934$

Stulz, R.M., 1983, The demand for foreign bonds, Journal of International Economics, 383-406.

Stulz, R.M., 1984, Currency preferences, purchasing power risks and the determination of exchange rates, Journal of Money, Credit and Banking 16, 302-316.

Stulz, R.M., 1987, An equilibrium model of exchange rate determination and asset pricing with nontraded goods and imperfect information, Journal of Political Economy 95 , 1024-1041.

Stulz, R.M. and W. Wasserfallen, 1992, Foreign equity investment restrictions: Theory and evidence, unpublished working paper, The Ohio State University, Columbus, 
Ohio.

Svensson, L., 1987, Currency prices, terms of trade and interest rates: A general equilibrium asset-pricing, cash-in-advance approach, Journal of International Economics $18,17-41$.

Tesar, L., and I.M. Werner, 1993, Home bias and the globalization of securities markets, unpublished working paper, Stanford University.

Uppal, R., 1991, Deviations from purchasing power parity and home equity preference, unpublished working paper, University of British Columbia, Vancouver, Canada.

Wheatley, S., 1988, Some tests of international equity integration, Journal of Financial Economics 21, 177-212. 
</ref_section> 